\title{
Do Marketing Talents Matters? Its Relationship to Marketing Capability and Performance
}

\author{
Lichung Jen ${ }^{1} \&$ Yichun Liu ${ }^{1}$ \\ ${ }^{1}$ Department of International Business, National Taiwan University, Taipei, Taiwan \\ Correspondence: Yichun Liu, College of Management, National Taiwan University, 1, Sec. 4, Roosevelt Rd. \\ Taipei 116, Taiwan. E-mail: d02724003@ntu.edu.tw
}

Received: November 13, 2018

Accepted: December 28, 2018 Online Published: January 24, 2019

doi:10.5539/ijms.v11n1p69

URL: https://doi.org/10.5539/ijms.v11n1p69

\begin{abstract}
The discussion of marketing capability on firms' performance has been well documented for the last two decades. Most of the previous studies regarding the measurement of marketing capability are based solitary on the attitude of top managers. However, employees' marketing talents are rarely discussed. This study, we propose a two-order factor hierarchy model utilizing a new pairwise survey approach to evaluate managers' marketing capability and employees' marketing talent. A preliminary questionnaire was developed to conduct an empirical study, of which four companies over 2,000 employees were surveyed. This study identified the positive impact of employee marketing talent and managerial marketing capability to organizational performance. Theoretical contribution, managerial implication and limitations are also discussed.
\end{abstract}

Keywords: marketing capability, marketing talent, performance

"We are placed here with certain talents and capabilities. ... and if we use our talents properly, we will be living the kind of life we should live."-John Glenn (April 9, 1959)

\section{Introduction}

The success of an organization depends heavily on members' talents and capabilities. In the same vein, effectively executing the marketing strategies will depend not only on manager's marketing capability but also employees' marketing talents. Marketing capability is a complex bundle of marketing knowledge and skills and is embedded in organizational process that increases effectiveness of converting resources into outputs and delivers firms' value propositions (Day, 1994). The discussion of the impact of marketing capability on firms' performance has been well documented for the last two decades. Most of the previous studies regarding the measurement of marketing capability are based solitary on the attitude of top managers. However, employees' marketing talents are rarely discussed. In recent years, due to the advancement of Internet technology, more and more companies are adopting horizontal organization, which empower individual employees to use their own rationality and conducts in making decisions. Thus, employees' marketing talents are becoming increasingly important to firms' performance. Moorman and Day (2016) urge researchers to study how marketing leaders and marketing employees contribute to firm performance. Hence, to what extent is an individual employee's marketing talents contributing to a firm's performance?

We begin with a literature review to investigate the construct of marketing capability and to help us deduce the proper definition and measurement of individual employees' marketing talents. A preliminary questionnaire was developed to conduct an empirical study, of which four companies and over 2,000 employees were surveyed. The result shows that employees' marketing talents significantly and positively contribute to organizational performance. Marketing capability is a mediator of the relationship between marketing talent and performance. Finally, the strategic implications of our newly developed measurements of marketing talents are discussed.

\section{Literature Review and Concept Development}

\subsection{Marketing Capability}

The concept of marketing capability has been proposed by Day (1994). They defined it as the capability to transform resources into valuable outcomes based on various marketing strategies. During the last two decades, we can summarize all related research into three different perspectives. First, from the marketing resources perspective, scholars have identified various marketing resources (e.g., marketing knowledge and skills, brand 
reputation, customer relationship, and marketing human capital), which can achieve competitive advantage in the market (Hooley, Greenley, Cadongan, \& Fahy, 2005; Morgen, Slotegraaf, \& Vorhis, 2009; Nath, Nachiappan, \& Ramanthan, 2010). They also investigated the marketing capability in terms of shaping routine for resources generating and management, such as marketing planning capability and marketing employee development capability (Piercy \& Morgan, 1994; Morgen et al., 2009; Orr, Bush, \& Vorhis, 2011). Second, from the viewpoint of marketing strategies and execution, an organization must acquire, integrate, and deploy these resources via various marketing strategies to deliver the marketing value. Those strategies include classical marketing mix strategies (Hooley, Broderick, \& Moeller, 1998; Vorhis \& Morgen, 2005), customer services and public relations activities (Vohris \& Yarbrough, 1998), and marketing implementation capability (Hooley et al., 1998; Vorhis \& Morgan, 2003; Morgan, Vorhis, \& Mason, 2009). Finally, from the dynamic point of view, firm should possess capabilities to sense and respond to the emerging customer needs, evolving channel relationships, and fierce environmental changes (Day, 1994; Palmatier, Houston, Dant, \& Grewal, 2013; Mu, 2015; Moorman \& Day, 2016). All of these capabilities are used in the literature to define marketing capability in detail and to test out their effects on firms' performances.

Most of these empirical studies apply senior executives/managers as key informants to evaluate the marketing capabilities of their own company directly (Greenley, Hooley, \& Rudd, 2005; Morgan et al., 2009) or benchmarking on their major rivals (Vorhies \& Morgan, 2005). Another research stream examines the relationship between marketing capability and firm performance via financial data, such as selling and spending (Kotabe, Srinivasan, Aulakh, 2002; Mizik \& Jacobson, 2003; Akdeniz, Gonzalez-Pardon, \& Calantone, 2010), market share (Moorman \& Slotegraaf, 1999), multi-input (e.g., stock of marketing expenditure, intangible resources, relationship expenditure, and installed customerbase) and multi-output (e.g., sales) efficiency (Nath et al., 2010; Dutta, Narashimhan, \& Rajiv, 1999) to portray the effect of marketing capability. Results of above researches provide evidence for the importance and positive contributions of marketing capability to business performance.

According to previous mentioned articles, marketing capabilities were investigated based on firm's marketing orientation and measured either through managers' subjective rating or firm-level aggregate data. Therefore, in this study, we denote this type of marketing capability as managerial marketing capability, namely, the ability of managers' shaping marketing orientations, goals and effective marketing strategies so as to navigate firms toward marketing excellence. Thus, following the literature we suggest:

Hypothesis 1: Managerial marketing capability is positively associated with its performance.

\subsection{Individual Marketing Talent}

Human capital has been recognized as an important asset to trigger marketing strategies (Hunt, 2000; Moorman \& Day, 2016; Zhao, 2017). Both managers and employees play a foundational role deriving firm's performance with different objects. Top managers aim to shape the value and orientation of an organization (Webster, 1988; Jaworski \& Kohli, 1993; Kirca, Jayachandran, \& Bearden, 2005), whereas employees as a route to carry out marketing tasks. Orr et al. (2011) discuss this importance in depth by emphasizing the firms' training and maintenances ability on marketing employees' knowledge and skills in terms of customer relationship and branding. In addition, to successfully implement marketing strategy requires not only simple participation from marketing people, but also work force from all departments. That is, the execution of marketing strategies always requires teamwork across departments. Therefore, employees from across all different departments and regardless of their positions should be provided with a certain degree of knowledge in marketing concepts which will benefit overall firm performance.

As firms adopt new marketing strategies, employees might first interpret these marketing strategies through their marketing knowledge, and then execute it in the way they conduct their work. Thus, we define the abilities of interpretation and execution as employee marketing talent. In line with managerial marketing capability, which describes the firms' marketing endowment and marketing sense, the employee marketing talents describe individual's marketing endowment and marketing sense. Employees with strong marketing talent denotes that they conduct better marketing concept in their daily work, having better sense of marketing, and can understand marketing strategy in a more consistent way of managers so as to pick up the strategy quickly and accurately. Thus, employees' marketing talent can flawlessly execute marketing strategies and contribute significantly to firm performance.

Hypothesis 2: Employees' marketing talent contributes positively to firm performance.

Furthermore, to successfully unfold employees' marketing talent, managers should possess strong marketing capability to shape the proper orientation and to lead the team toward excellence. Hence, we propose the role of 
marketing capability as a mediator in Hypothesis 3 .

Hypothesis 3: Employees' marketing talent contributes positively to managerial marketing capability.

\section{Methodology}

\subsection{Construct Specification}

The measurement of marketing capability can be categorized into three groups. The first group emphasizes the fundamental elements of marketing activities, such as marketing mix. The second group contains managerial elements including marketing management, information management, planning, channel management, and customer relationship management. Market elements such as market research, selling, and forecasting are categorized into the third group (Vorhies, 1998; Vorhies, Harker, \& Rao, 1999; Vorhies \& Morgan, 2005; Morgan et al., 2009).

Summarizing the above commonly used measurements of marketing capability, there are 79 constructs consisting of 286 items. We reexamined all items, pooled similar questions, and categorized them into four different constructs: product, promotion, market research, and relationship. The sub-constructs of these four categories are presented in Figure 1. Since measurement construct/framework used in literatures are derived before the popularization of media marketing and big data analysis, we aimed to put this missing puzzle piece into the framework. Descriptions of 123 questions were reviewed by several expert judges, which consist of various marketing professors, doctoral students, and senior managers in various firms, to reduce the initial item bank. Items were refined several times based on feedback. A hierarchy construct consisting of 50 items were retained and applied in the pretest process.

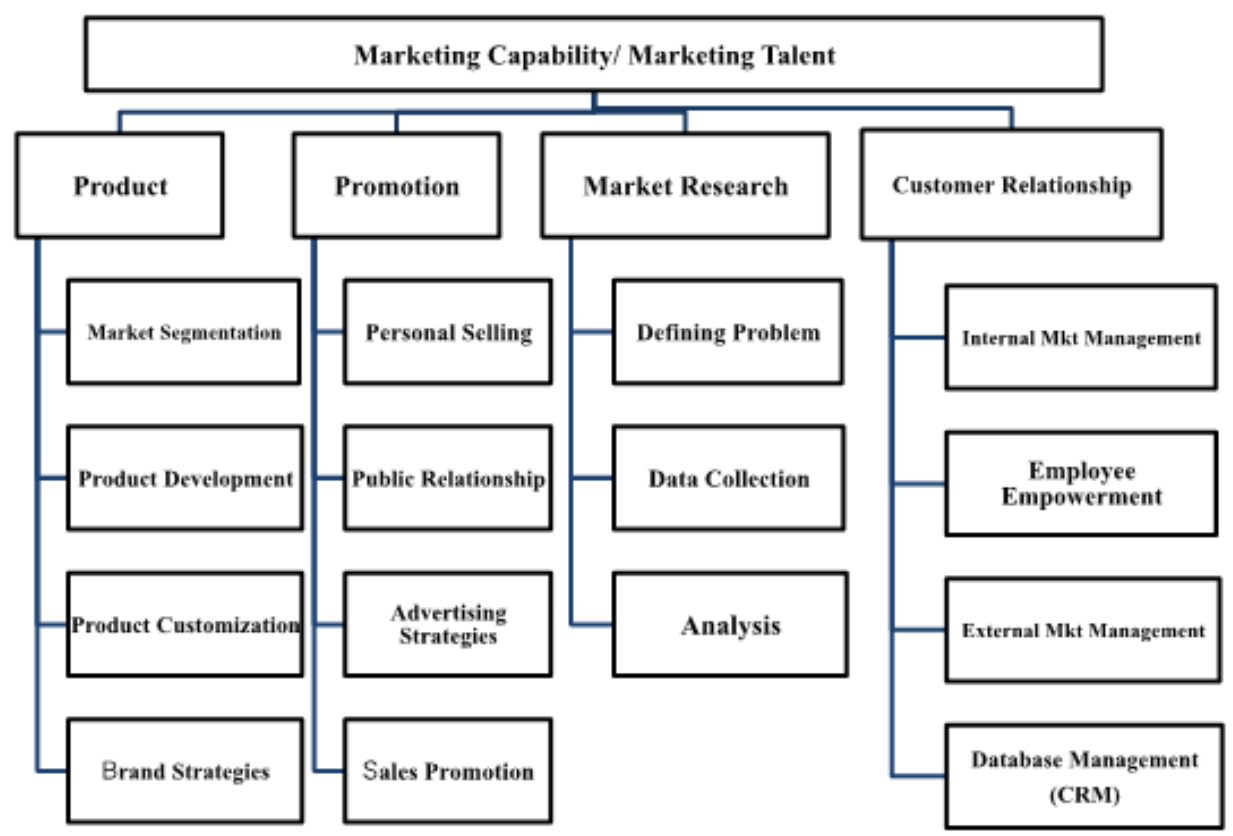

Figure 1. Hierarchy construct of marketing capability/marketing talent

\subsection{Scale Development}

Subjective Likert scales are widely adopted by scholars to evaluate firms' various marketing capabilities (McKee, Varadrajan, \& Pride, 1989; Piercy \& Morgan, 1994; Hooley et al., 1998; Vorhies, 1998; Vorhies \& Yarbrough, 1998; Vorhies et al., 1999; Morgan, Vorhis, \& Katsikas, 2003; Vorhies \& Morgan, 2003, 2005; Morgan et al., 2009; Orr et al., 2011; Mu, 2015). However, informant rating may be sensitive to its experience, position, focus goal, or different referencing of competitors as a benchmark (Moorman \& Day, 2016). To overcome this drawback, we standardize the survey response into three narrative sentences for each item. For example, we transferred the traditional question...

"Please rate your business unit relative to your major competitor in terms of its marketing capabilities in the Ability to effectively segment and target market. Seven-point scale running -3("much worse than competitor") to +3 ("much better than competitor") (Vorhis \& Morgan, 2005)" 
by asking:

What is the segmentation/ positioning strategy of your company? (Select only one statement that best describe your company.)

a) We segment markets and position our product base on its functions/characteristics.

b) We segment markets and position our product base on consumers' demographical information, such as gender, age, and income.

c) We segment markets and position our product base on the information of consumers' lifestyle or the benefits of using the products and etc.

In turn, each statement denotes either having satisfied (statement a), good (statement b), or excellent (statement c) marketing capability.

\section{Data Collection and Measurement}

\subsection{Pretest}

A pretest sample set contains 1,256 respondents. Participants included $4.22 \%$ manager and $95.78 \%$ employee, ranging in working age from 0 to above 40 years. An analysis of marketing capability constructs was performed using confirmatory factor analysis (CFA). The result of a final CFA model contains 15 items with excellent overall fit $\left(\chi^{2}(88)=214.908, \mathrm{p}<.00, \mathrm{RMSEA}=.0350, \mathrm{GFI}=.979, \mathrm{AGFI}=.972, \mathrm{NFI}=.944, \mathrm{CFI}=.966\right)$.

\subsection{Data Sources}

Questionnaires were distributed to managers and employees of 4 Taiwanese companies across textile, footwear, and playground industries. Descriptions of each items were randomly presented in different versions of the questionnaire. Following the collection of marketing capability and marketing talent, we also collected the performance evaluation of each employee from companies' internal human resource (HR) database. Due to confidentiality, individual performances were categorized into 5 levels, excellent (top 20\%), good (60-79\%), satisfactory (40-69\%), poor (20-39\%), and inferior (bottom 20\%), depending on their original performance. A final data set contains 3,134 responses, of which 68 were deleted due to inadequate response time (less than 5 minutes) and information scarcity of performance, yielding 2,053 usable surveys from textile $(1,256)$, footwear (610), playground A (133), and playground B (54) companies (a response rate of 97.83\%).

\subsection{The Dyads Units of Analysis}

To examine the validity of marketing capability versus marketing talent, we need to pair the ability of key informants in different positions within a department to provide accurate analysis of capability-talent relationships. We constructed a coding book to categorize informants into managerial and employee groups according to their positions. Managers and supervisors of departments or divisions are indicated as management level, others are recognized as employees. We then identified several analysis units within the firms based on firm's departments and locations of subsidiary. In sum, there are 37 units of position dyads in our sample set. The statistical descriptions and correlations of variables are presented in Table 1.

\subsection{Dependent and Independent Variables}

Performance. To measure the performance, we coded the interval data: 5 represents excellent, 4 as good, 3 as satisfied, 2 as poor, and 1 as inferior performance. The average performance of all members within the same analysis units were used to measure the performance.

Marketing capability. Responses from various version of questionnaire were first reordered from the random sorting statements and then combined. Descriptions of items are coded in term of 3 different levels: 1 as excellent, 0 as good, and -1 as satisfied. The marketing capability of analysis units is measured by taking the average of managers' responses within the units.

Marketing talent. Measurements of marketing talent from employee follow the same process as marketing capability. We adapt the same coding book and take the average of employee's response within the unit to measure its marketing talent.

\section{Estimation and Results}

Our theoretical model suggests that marketing talents contribute positively to firm performance and is mediated by managerial marketing capability. To test this relationship, as Baron and Kenny's (1986) suggested, we should observe that (1) marketing talent positively contributes to firm performance, (2) marketing capability positively contributes to firm performance, and (3) the direct effect of marketing talent on firm performance is weaker 
when the effect of marketing capability is accounted for. We conduct 3 models to test our hypotheses. The results are presented in Table 1. In Model 1 and 2, we find both marketing capability and marketing talent positively contribute to performance (MT, $\beta=0.74$, $\mathrm{P}$-value $=0.026 ; \mathrm{MC}, \beta=0.96$, $\mathrm{P}$-value $<0.001$ ), which is in consist with the literatures. Thus, Hypothesis 1 and 2 have been supported. When we include both marketing capability and marketing talent in Model 3, it significantly weakens the effect of marketing talent on firm performance, indicating that marketing capability has a completely mediation effect. Therefore, the empirical results support our theoretical framework.

\section{Discussion and Conclusion}

Our study provides the clarification of the important relationship between employees' marketing endowment and sense and managers' marketing capability. In our empirical study, we present that as has been formerly supported, marketing capability is a significant predictor of firm performance. We also find that marketing talent is another important factor to enhance firm performance. However, this effect must contribute through a positive managerial marketing capability. One might wonder the explanation ability of our proposed model due to the $\mathrm{R}^{2}$ and adjusted- $\mathrm{R}^{2}$ values of our models. One explanation is that cross-sectional model based on the survey commonly has higher variation than panel data, therefore, low $\mathrm{R}^{2}$ value is the norm. Another plausible reason might be that the performance of analysis unit is measured by a proxy variable, the employee evaluation of companies' internal human resource, which usually contains multiple aspect of working performance evaluations and rarely have a single indicator for employees' marketing performance. Despite the low $\mathrm{R}^{2}$ and adjusted- $\mathrm{R}^{2}$ values of our models, the F-test significant at 5\% level, our models suggested that employees' marketing talents and managers' managerial marketing capability are one of the factors that can positively improve the overall performance of the company. This align with the result suggested in the literatures that marketing capability partly contributes to a firms' overall performance.

The contributions of this study are as follow. First, we identified the importance of employee marketing talent and managerial marketing capability to firm performance by using a new developed measurement. We focused on four elements of marketing capability and marketing talent: product, promotion, market research, and relationship. These elements play the most important role in evaluating firms marketing activities.

Table 1. Descriptive statistics and correlation table, and empirical results

\begin{tabular}{|c|c|c|c|c|c|c|c|c|c|}
\hline \multirow[t]{3}{*}{ Variables } & \multirow{3}{*}{$\begin{array}{l}\text { Mean } \\
\text { (St.d) }\end{array}$} & \multirow[t]{3}{*}{ Min } & \multirow[t]{3}{*}{ Max } & \multirow{2}{*}{\multicolumn{3}{|c|}{ Correlation of Variables }} & \multicolumn{3}{|c|}{ Dependent Variables } \\
\hline & & & & & & & \multirow{2}{*}{$\begin{array}{l}\text { MC } \\
\text { Model 1 } \\
\end{array}$} & \multicolumn{2}{|c|}{ Performance } \\
\hline & & & & $\mathrm{PF}$ & MT & $\mathrm{MC}$ & & Model 2 & Model 3 \\
\hline Perf. & $\begin{array}{l}3.27 \\
(0.45)\end{array}$ & 2.43 & 4.14 & 1.00 & & & & & \\
\hline Constant & & & & & & & $\begin{array}{l}3.14 * * * \\
(0.09)\end{array}$ & $\begin{array}{l}3.18 * * * \\
(0.07)\end{array}$ & $\begin{array}{l}3.17 * * * \\
(0.09)\end{array}$ \\
\hline MT & $\begin{array}{l}0.18 \\
(0.22)\end{array}$ & -0.21 & 0.64 & 0.37 & 1.00 & & $\begin{array}{l}0.74 * * \\
(0.32)\end{array}$ & & $\begin{array}{l}0.06 \\
(0.41)\end{array}$ \\
\hline $\mathrm{MC}$ & $\begin{array}{l}0.10 \\
(0.24)\end{array}$ & -0.48 & 0.52 & 0.51 & 0.69 & 1.00 & & $\begin{array}{l}0.96^{* * * *} \\
(0.27)\end{array}$ & $\begin{array}{l}0.91 * * \\
(0.38)\end{array}$ \\
\hline $\mathrm{R}^{2}$ & & & & & & & 0.13 & 0.26 & 0.26 \\
\hline $\operatorname{Adj}-\mathrm{R}^{2}$ & & & & & & & 0.11 & 0.24 & 0.22 \\
\hline F-Value & & & & & & & $5.38 * *$ & $12.16^{* * *}$ & $5.92 * * *$ \\
\hline
\end{tabular}

Note. (1) $\mathrm{N}=37$. (2) The dependent variable for Model 1 is marketing capability, for Models 2-3 are performance. Standard errors are presented (in parentheses). (3) $*, * *$, and $* * *$ represent the $10 \%, 5 \%$, and $1 \%$ levels of significance, respectively.

Secondly, to overcome the effect of inconsistent subjective rating, a new survey approach is proposed. Items are presented in the form of multiple choices instead of traditional Liker-point scale. In addition, possible answers of each item are listed as three identical ordered-level descriptions. Thirdly, the modern marketing technique, such as the usage of social media, ability of managing database, and data collection are also contained in our analysis framework. Fourthly, Moorman and Day (2016) proposed a question of how do marketing leaders and marketing employees contribute to firm performance. This study suggests that managerial marketing capability and employee marketing talent contribute differently to firm performance. Marketing capability is a mediator of the relationship between marketing talent and unit performance. Finally, our framework enables company to 
evaluate the individual marketing talent of employee and customize a marketing training program for each employee. Thus, to successfully execute marketing strategies and marketing tasks of a firm requires all firm's employees to have certain degree of marketing talent so as to benefits of value appropriation. Overall, our findings provide insights into two important implications. First, our finding suggests that for firms intend to improve the performance, should enhance not only managers' marketing capability but also employees' marketing talent. Second, marketing capability completely meditates the positive effect of marketing talent on firm performance.

This study has several limitations that could be served for the future research topics. The marketing talent scale in this study is developed and tested in service sector of two countries with similar working culture background, to examine whether the scales can be applied in countries with different working culture or other sectors would enrich in understanding the contribution of different type of marketing talent on firms' performance. In addition, this study focuses on only the aggregate contribution of marketing talent and marketing capability on the performance, investigating antecedents of marketing talent would prove to be an interesting line of future study. Similarly, in the context of services marketing theory, detailed marketing talent/capability scale can be used to see if both talent and capabilities have an effect toward the level of implementation of internal marketing within the organization. Finally, future research could also be carried on at understanding to what extent of employee loyalty toward the company can be put into relation with marketing talents and employee work motivation.

\section{References}

Akdeniz, M. B., Gonzalez-Padron, T., \& Calantone, R. J. (2010). An Integrated Marketing Capability Benchmarking Approach to Dealer Performance through Parametric and Nonparametric Analyses. Industrial Marketing Management, 39(1), 150-160. https://doi.org/10.1016/j.indmarman.2008.05.002

Baron, R. M., \& Kenny, D. A. (1986). The Moderator-mediator Variable Distinction in Social Psychological Research: Conceptual, Strategic, and Statistical Considerations. Journal of Personality and Social Psychology, 51(6), 1173-1182. https://doi.org/10.1037/0022-3514.51.6.1173

Day, G. S. (1994). The Capabilities of Market-Driven Organizations. Journal of Marketing, 58(4), 37-52. https://doi.org/10.2307/1251915

Dutta, S., Narasimhan, O., \& Rajiv, S. (1999). Success in High-Technology Markets: Is Marketing Capability Critical? Marketing Science, 18(4), 547-568. https://doi.org/10.1287/mksc.18.4.547

Greenley, G. E., Hooley, G. J., \& Rudd, J. M. (2005). Market Orientation in a Multiple Stakeholder Orientation Context: Implications for Marketing Capabilities and Assets. Journal of Business Research, 58(11), 1483-1494. https://doi.org/10.1016/j.jbusres.2004.07.004

Hooley, G. J., Greenley, G. E., Cadogan, J. W., \& Fahy, J. (2005). The Performance Impact of Marketing Resources. Journal of Business Research, 58, 18-27. https://doi.org/10.1016/S0148-2963(03)00109-7

Hooley, G. J., Broderick, A., \& Möller, K. (1998). Competitive Positioning and the Resource-based View of the Firm. Journal of Strategic Marketing, 6(2), 97-116. https://doi.org/10.1080/09652549800000003

Hunt, S. D. (2000). A General Theory of Competition: Resources, Competences, Productivity, Economic Growth. Thousand Oaks, CA: Sage. http://dx.doi.org/10.4135/9781452220321

Jaworski, B. J., \& Kohli, A. K. (1993). Market Orientation: Antecedents and Consequences. Journal of Marketing, 57(3), 53-70. https://doi.org/10.2307/1251854

Kirca, A. H., Jayachandran, S., \& Bearden, W. O. (2005). Market Orientation: A Meta-Analytic Review and Assessment of Its Antecedents and Impact on Performance. Journal of Marketing, 69(2), 24-41. https://doi.org/10.1509/jmkg.69.2.24.60761

Kotabe, K., Srinivasan, S. S., \& Aulakh, P. (2002). Multinationality and Firm Performance: The Moderating Role of R\&D and Marketing Capabilities. Journal of International Business Studies, 33(1), $79-97$. https://doi.org/10.1057/palgrave.jibs.8491006

McKee, D. O., Varadarajan, P. R., \& Pride, W. M. (1989). Strategic Adaptability and Firm Performance: A Market-Contingent Perspective. Journal of Marketing, 53(3), 21-35.

Moorman, C., \& Day, G. S. (2016). Organizing for Marketing Excellence. Journal of Marketing, 80(Nov.), 6-35. https://doi.org/10.2307/1251340

Morgan, N. A., Slotegraaf, R. J., \& Vorhies, D. W. (2009). Linking Marketing Capabilities with Profit Growth. International Journal of Research in Marketing, 26(4), 284-293. 
https://doi.org/10.1016/j.ijresmar.2009.06.005

Morgan, N. A., Vorhies, D. W., \& Mason, C. H. (2009). Market Orientation, Marketing Capabilities, and Firm Performance. Strategic Management Journal, 30(8), 909-920. https://doi.org/10.1002/smj.764

Morgan, N. A., Zou, S., Vorhies, D. W., \& Katsikeas, C. S. (2003). Experiential and Informational Knowledge, Architectural Marketing Capabilities, and the Adaptive Performance of Export Ventures: A Cross-National Study. Decision Sciences, 34(2), 287-321. https://doi.org/10.1111/1540-5915.02375

Mu, J. (2015). Marketing Capability, Organizational Adaptation and New Product Development Performance. Industrial Marketing Management, 49,151-166. https://doi.org/10.1016/j.indmarman.2015.05.003

Nath, P., Nachiappan, S., \& Ramanathan, R. (2010). The Impact of Marketing Capability, Operations Capability and Diversification Strategy on Performance. Industrial Marketing Management, 39, $317-329$. https://doi.org/10.1016/j.indmarman.2008.09.001

Orr, L. M., Bush, V. D., \& Vorhies, D. W. (2011). Leveraging Firm-level Marketing Capabilities with Marketing Employee Development. Journal of Business Research, 64(10), 1074-1081. https://doi.org/10.1016/j.jbusres.2010.11.003

Palmatier, R. W., Mark B. H., Rajiv P. D., \& Dhruv, G. (2013). Relationship Velocity: Toward a Theory of Relationship Dynamics. Journal of Marketing, 77(1), 13-30. https://doi.org/10.1509/jm.11.0219

Piercy, N. F., \& Morgan, N. A. (1994). The Marketing Planning Process: Behavioral Problems Compared to Analytical Techniques in Explaining Marketing Plan Credibility. Journal of Business Research, 29(3), 167-178. https://doi.org/10.1016/0148-2963(94)90001-9

Vargo, S. L., \& Lusch, R. F. (2004). Evolving to a New Dominant Logic for Marketing. Journal of Marketing, 68(1), 1-17. https://doi.org/10.1509/jmkg.68.1.1.24036

Vorhies, D. W. (1998). An Investigation of the Factors Leading to the Development of Marketing Capabilities and Organizational Effectiveness. Journal of Strategic Marketing, 6(1), 3-24. https://doi.org/10.1080/096525498346676

Vorhies, D. W., \& Morgan, N. A. (2003). A Configuration Theory Assessment of Marketing Organization Fit with Business Strategy and Its Relationship with Marketing Performance. Journal of Marketing, 67(1), 100-115. https://doi.org/10.1509/jmkg.67.1.100.18588

Vorhies, D. W., \& Morgan, N. A. (2005). Benchmarking Marketing Capabilities for Sustainable Competitive Advantage. Journal of Marketing, 69(1), 80-94. https://doi.org/10.1509/jmkg.69.1.80.55505

Vorhies, D. W., Harker, M., \& Rao, C. P. (1999). The Capabilities and Performance Advantages of Market-driven Firms. European Journal of Marketing, 33(11/12), 1171-1202. https://doi.org/10.1108/03090569910292339

Vorhies, D. W., \& Yarbrough, L. (1998). Marketing's Role in the Development of Competitive Advantage: Evidence from the Motor Carrier Industry. Journal of Market Focused Management, 2(4), 361-386.

Webster, F. E. (1988). The Rediscovery of the Marketing Concept. Business Horizons, 31(3), 29-39. https://doi.org/10.1016/0007-6813(88)90006-7

Zhao, C. (2017). An Investigation and System Innovation of Marketing Talents Training Mode. Boletín Técnico, $55(10)$.

\section{Copyrights}

Copyright for this article is retained by the author, with first publication rights granted to the journal.

This is an open-access article distributed under the terms and conditions of the Creative Commons Attribution license (http://creativecommons.org/licenses/by/4.0/). 